\title{
In Utero and Early-Life Conditions and Adult Health and Disease
}

\section{Citation}

Grandjean, Philippe, and Jerrold Heindel. 2008. In Utero and Early-Life Conditions and Adult Health and Disease. New England Journal of Medicine 359 (14): 1523.

\section{Published Version}

doi:10.1056/NEJMra0708473

\section{Permanent link}

http://nrs.harvard.edu/urn-3:HUL.InstRepos:34787303

\section{Terms of Use}

This article was downloaded from Harvard University's DASH repository, and is made available under the terms and conditions applicable to Other Posted Material, as set forth at http:// nrs.harvard.edu/urn-3:HUL.InstRepos:dash.current.terms-of-use\#LAA

\section{Share Your Story}

The Harvard community has made this article openly available.

Please share how this access benefits you. Submit a story.

Accessibility 


\section{In Utero and Early-Life Conditions and Adult Health and Disease}

TO THE EDITOR: In their article on the developmental origin of disease, Gluckman et al. (July 3 issue $)^{1}$ state that "an altered long-term risk of disease is initially induced through adaptive responses that the fetus or infant makes to cues from the mother about her health or physical state." This rather narrow definition and the overall focus of the review leave out adverse responses due to maternal exposures to environmental chemicals, occupational hazards, drugs, tobacco smoking, or infection. These factors are likely to make a very large contribution to adult diseases of developmental origin, and they have the advantage of being potentially preventable. ${ }^{2}$ Risk assessment of environmental hazards must therefore include the effects of developmental exposures to stimulate better protection of the most vulnerable life stages.

Philippe Grandjean, M.D., Ph.D.

Harvard School of Public Health

Boston, MA 02215

pgrand@hsph.harvard.edu

Jerrold J. Heindel, Ph.D.

National Institute of Environmental Health Sciences Research Triangle Park, NC 27709

1. Gluckman PD, Hanson MA, Cooper C, Thornburg KL. Effect of in utero and early-life conditions on adult health and disease. N Engl J Med 2008;359:61-73.

2. Grandjean P, Bellinger D, Bergman A, et al. The Faroes statement: human health effects of developmental exposure to chemicals in our environment. Basic Clin Pharmacol Toxicol 2008; 102:73-5.

TO THE EDITOR: The article by Gluckman et al. highlights an ongoing fundamental change in medical thinking known as the life-course approach to the development of disease. The "developmental model" of chronic diseases postulates that early-life events affect individual differences in vulnerability to lifestyle and environment. This concept is supported by studies of in utero or atbirth conditions on future diseases by the fact that differences in adult lifestyles only partially explain the development of diseases. ${ }^{1}$

Considering the aging of the worldwide population and the associated increase in the prevalence of chronic diseases, research on the initiating events of such diseases is valuable and necessary, but research on possible synergism or antagonism between in utero and childhood or adulthood conditions on elderly health could be as important for future public health policies. For example, the interaction between education which has been found to be inversely associated with both multiple chronic conditions ${ }^{2}$ and $\mathrm{Alz}-$ heimer's disease ${ }^{3}$ in the elderly population - and in utero environment might be a pioneering project in this growing research field.

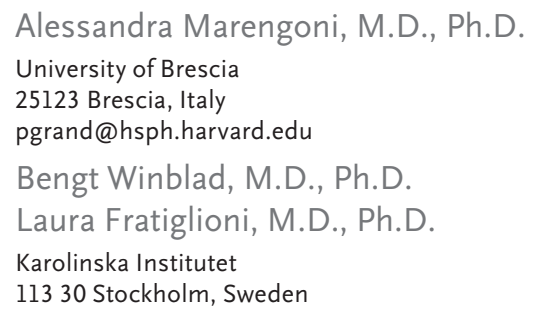

1. Gluckman P, Hanson M, eds. Developmental origins of health and disease. Cambridge, England: Cambridge University Press, 2006.

2. Marengoni A, Winblad B, Karp A, Fratiglioni L. Prevalence of chronic diseases and multimorbidity among the elderly population in Sweden. Am J Public Health 2008;98:1198-200.

3. Karp A, Kåreholt I, Qiu C, Bellander T, Winblad B, Fratiglioni L. Relation of education and occupation-based socioeconomic status to incident Alzheimer's disease. Am J Epidemiol 2004; 159:175-83.

TO THE EDITOR: Gluckman et al. review evidence on the effects of fetal conditions on adult disease. However, an important potential player is being left out of their discussion. Prenatal inflammation, reflected by chorioamnionitis and the fetal inflammatory response syndrome, has been recognized as a fetal condition that contributes to disease in the perinatal period and beyond, mainly affecting the developing lung and brain. ${ }^{1,2}$ The evidence is increasing that prenatal exposure to inflammation in utero is related to disease, later in childhood, involving the affected organs and is associated with physician-diagnosed asthma, ${ }^{3}$ recurrent wheezing, ${ }^{3}$ autistic behavior, ${ }^{4}$ and adverse neurodevelopmental outcome. ${ }^{5}$ Experimental chorioamnionitis results in pathogenic programming of the fetal immune response, endotoxin tolerance, and crucial developmental changes, suggesting an important programming effect. ${ }^{1}$ Thus, accumulating evidence implies an important role of antenatal inflammation in fetal programming and subsequent disease development, the mechanisms 
of which need further investigation. Considering the immature stage of the exploration of these effects, we may well currently be looking at the tip of the iceberg, anticipating potential links with adult pulmonary and neurologic diseases like chronic obstructive pulmonary disease and dementia.

Jasper V. Been, M.D.

Boris W. Kramer, M.D., Ph.D.

Luc J.I. Zimmermann, M.D., Ph.D.

Maastricht University Hospital

6202 AZ Maastricht, the Netherlands

jasper.been@mumc.nl

1. Kramer BW. Antenatal inflammation and lung injury: prenatal origin of neonatal disease. J Perinatol 2008;28:Suppl 1:S21S27.

2. Romero R, Gotsch F, Pineles B, Kusanovic JP. Inflammation in pregnancy: its roles in reproductive physiology, obstetrical complications, and fetal injury. Nutr Rev 2007;65:S194-202.

3. Kumar R, Yu Y, Story RE, et al. Prematurity, chorioamnionitis, and the development of recurrent wheezing: a prospective birth cohort study. J Allergy Clin Immunol 2008;121:878-84.

4. Limperopoulos C, Bassan H, Sullivan NR, et al. Positive screening for autism in ex-preterm infants: prevalence and risk factors. Pediatrics 2008;121:758-65.

5. Redline RW, Minich N, Taylor HG, Hack M. Placental lesions as predictors of cerebral palsy and abnormal neurocognitive function at school age in extremely low birth weight infants (<1 kg). Pediatr Dev Pathol 2007;10:282-92.
THE AUTHORS REPLY: We are pleased with the interest in our review, particularly, as noted, concerning the relevance of developmental exposures (environmental toxins, smoking, and alcohol consumption), intermediary phenotypes (chronic lowgrade inflammation), and health outcomes (aging and cognitive decline). Although we focused on metabolic, cardiovascular, and bone disease, the areas most developed, we have little doubt that developmental plasticity and epigenetic change have much greater involvement in the etiology of human disease than has previously been considered. We would urge further research to clarify the involved epigenetic mechanisms, to develop risk-prediction tools that might be applied throughout the life course, and to delineate preventive and interventional strategies.

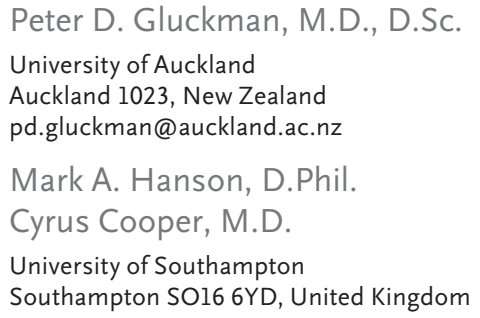

\section{A Case of Conjugal Azathioprine-Induced Contact Hypersensitivity}

TO THE EDITOR: A man in his early 30s presented with an intermittent eczematous eruption over the shaft of his penis and scrotum (Fig. 1A). His wife was initially concerned about his fidelity, but a careful history-taking revealed that the rash coincided with his wife's intermittent courses of azathioprine for Crohn's disease. During four courses of such treatment over a 4-year period, her vaginal secretions were yellow, which raised the possibility of secretion of azathioprine or its metabolites that could have led to allergic contact dermatitis in the husband.

Further investigation was undertaken. Both the man and his wife had normal thiopurine methyltransferase levels. Epicutaneous patch testing of petrolatum alone or 1 to $10 \%$ of the drug in petrolatum was performed as previously described. ${ }^{1}$ Azathioprine (pure and tablet forms), its major breakdown product 6-mercaptopurine, and all available tablet excipients were tested on both partners. The husband, but not the wife, reacted to the tablet and pure forms of azathioprine only (Fig. 1B).
The presence of drug-specific lymphocytes in the husband's peripheral-blood mononuclear cells was assessed by means of the lymphocyte transformation test, ${ }^{2}$ but no response was seen, probably reflecting the inherent antilymphocyte activity of azathioprine. However, as shown with the use of an enzyme-linked immunosorbent spot assay, ${ }^{3}$ both azathioprine and 6-mercaptopurine induced the release of interferon- $\gamma$ from lymphocytes (50 and 70 positive cells per million, respectively, vs. 4 positive cells per million in the absence of drug) (Fig. 1C and 1D). No response was seen in controls (see the Supplementary Appendix, available with the full text of this letter at www. nejm.org). These data, in conjunction with the skin-test results, were interpreted to indicate that the husband had a hypersensitivity to 6-mercaptopurine or a metabolite of 6-mercaptopurine. The negative skin test for 6-mercaptopurine probably reflected its water solubility, causing it to penetrate into the epidermis much less than azathioprine.

Azathioprine is inactive until converted to 6-mercaptopurine and methyl-nitro-thioimidazole 